\title{
Water salinity and benthic macrophyte communities are the key variables defining the distribution pattern of benthic faunal assemblages in the shallow water areas of the Gulf of Riga
}

\author{
Jonne Kotta \\ Estonian Marine Institute, University of Tartu, Mäealuse 14, 12618 Tallinn, Estonia; jonne.kotta@sea.ee \\ Received 5 October 2012, revised 25 October 2012, accepted 25 October 2012

\begin{abstract}
The distribution of shallow water macrozoobenthic assemblages of the Gulf of Riga is analysed in relation to water current velocity, salinity, sediment type, ice disturbance, eutrophication, and benthic macrophytes. Salinity and benthic macrophyte communities described most of the variability in both the abundance and biomass structure of benthic invertebrates. In addition, surface chlorophyll $a$ also contributed to the variability of benthic invertebrate biomass. Benthic invertebrate assemblages in the vicinity of the Daugava and Pärnu rivers experience higher nutrient loading and feeders. Benthic invertebrate communities in other regions of the Gulf of Riga were typical for the mildly disturbed areas of the northern Baltic Sea. Compared to the situation in the 1960s, no substantial increase in the abundance and biomass values of macrozoobenthos was observed as could be expected from the basinwide trend of increasing eutrophication.
\end{abstract} \\ were therefore characterized by a lower species number and higher biomass of benthic suspension
}

Key words: Baltic Sea, distribution, benthic invertebrates, benthic macrophytes.

\section{INTRODUCTION}

Contrary to the intertidal areas of the oceanic coasts (e.g. Terlizzi \& Schiel, 2009), the large-scale patterns of benthic invertebrate communities in shallow water macrophyte habitats are not well studied in the Baltic Sea range. The majority of published papers focus on sedimentation and deeper areas (e.g. Laine et al., 2007; Kotta et al., 2007). When shallow water macrophyte communities are studied emphasis is only rarely placed on benthic macrophytes (Kautsky \& Van der Maarel, 1990; Kautsky et al., 1999). This is quite surprising considering the specificity of the Baltic Sea ecosystem and the potential uniqueness of how environmental variables shape its local populations.

The Gulf of Riga is a relatively shallow and closed water basin in the eastern Baltic Sea characterized by a fairly high riverine input from its extensive drainage area. Therefore, the communities are composed of a specific mixture of freshwater, brackish-water, and marine species (Kotta et al., 2008). Although the nutrient loading into the Gulf of Riga is high and the basin is considered to be 
among the most eutrophied areas in the Baltic Sea (Suursaar, 1995; Ojaveer, 1997; Kotta et al., 2008), the coastal areas of the Gulf of Riga support healthy macrophyte assemblages with the biomass of perennial species exceeding the values reported elsewhere in the Baltic Sea range (Kautsky et al., 1999).

Benthic invertebrates have been often used to assess the state of an aquatic environment because they are long-lived, sessile, and easy to collect and determine (e.g. Leppäkoski, 1975; HELCOM, 1993). The earliest quantitative surveys of benthic invertebrates in the Gulf of Riga were carried out in the 1950s (Shurin, $1953,1960,1961)$. These investigations were followed by the profound studies by Järvekülg (1961, 1962, 1979). Both series of investigations concentrated mainly on the macrozoobenthos inhabiting the soft substrate, that is the deeper part of the basin. Since then no concise work about the benthic invertebrates of the whole gulf has been published and most papers deal with the impact of the Pärnu or Daugava rivers (e.g. Lagzdinšs, 1975; Kotta \& Kotta, 1995; Kotta et al., $2009 \mathrm{~b}$ ). Hence, the extensive coastal areas of the Gulf of Riga are almost overlooked in terms of benthic invertebrates and we are still not aware how sensitive these communities are to changes in human induced pressures and climate conditions.

The objective of this investigation is to provide the first quantitative data about the distribution of benthic invertebrates in the shallow water range of the Gulf of Riga. As the coastal zone controls exchange, storage, and transformation processes of materials, knowledge about the structure and functions of benthic assemblages in this zone is fundamental for understanding the functioning of the system as a whole. Scuba diving made it possible to describe quantitatively the zoobenthic assemblages on hard substrate, but also contributed to better distinction between true sediment- and macrophyte-dwelling species. The distribution of benthic invertebrates was related to environmental parameters such as water current velocity, salinity, sediment type, ice disturbance, eutrophication, and benthic macrophytes. Most studies dealing with the shallow water benthic fauna have neglected benthic macrophytes. Finally, the results will be compared with the historical data in the area.

\section{MATERIAL AND METHODS}

Sampling was performed in August 1995 and 1996 on 10 transects located around the whole coastline of the Gulf of Riga (Fig. 1). The northern part of the gulf is characterized by a wide coastal zone with a diverse bottom topography and macrophyte community, and the southern side by a narrower sandy coastline and hard bottom substrate in the deeper parts of the littoral zone.

The samples were collected with a Tvärminne sampler (Kangas, 1972) on sand and gravel bottoms and a suction sampler (Hiscock \& Hoare, 1973) on hard bottom types like boulders and solid limestone floor. The sampling area of both samplers is $314 \mathrm{~cm}^{2}$. Three replicate samples were generally taken from 10 transects each containing 3 sites (a total of 94 samples), of which 19 were 


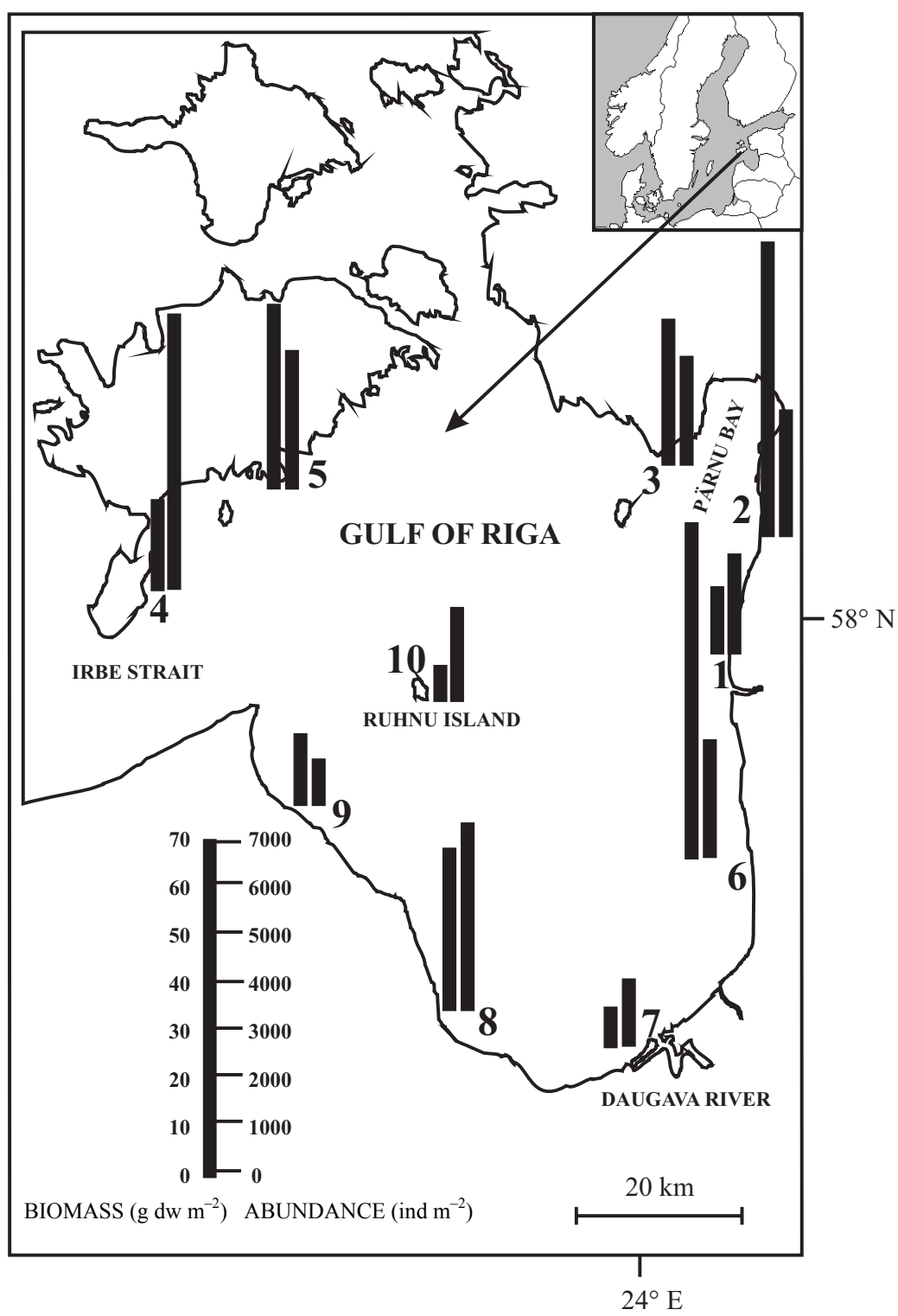

Fig. 1. Study area. Numbers indicate the location of the transects. The left bar shows the average dry weight, the right bar the average abundance of benthic invertebrates in the transect.

unvegetated (56 samples), 6 sites had vascular plants (18 samples), and 7 sites algal (filamentous algae, Fucus vesiculosus L. or Furcellaria lumbricalis J. V. Lamour) vegetation (20 samples). The sampling depth varied from 0.1 to $6.0 \mathrm{~m}$. Samples below $0.5 \mathrm{~m}$ were taken by SCUBA diving. Sampling sites were chosen to cover all possible sediment types and macrophytobenthic communities. In each site the type of substrate (stone, boulder, gravel, sand, silt, clay, or mixed), depth, and dominant plant species were recorded. 
Material was sieved through a net of $0.25 \mathrm{~mm}$ mesh size and preserved in $4 \%$ buffered seawater formalin solution. In the laboratory animals were counted under binocular microscope. Dry weights were obtained (to the nearest $0.1 \mathrm{mg}$ ) after drying the material at $70^{\circ} \mathrm{C}$ for 60 hours. Molluscs were weighed with shells.

The values of water temperature, salinity, and water current velocity were obtained from the results of hydrodynamic model calculations from the early April 1995 to the early August 1996. The calculations were based on the COHERENS model, which is a primitive equation ocean circulation model. The model was formulated with spherical coordinates on a $1^{\prime} \times 1^{\prime}$ minute horizontal grid and 30 vertical sigma layers. The model was forced with hourly meteorological fields of $2 \mathrm{~m}$ air temperature, wind speed, wind stress vector, cloud cover, and relative humidity. The meteorological fields were obtained from an operational atmospheric model. The model was validated against water level, temperature, salinity, and water velocity measurements from the study area (Bendtsen et al., 2009).

The Finnish Meteorological Institute provided the long-term averages of ice cover and thickness over the study area. Ice cover and thickness were produced on daily basis at a nominal resolution of $500 \mathrm{~m}$ and were based on the most recent available ice chart and a synthetic aperture radar (SAR) image. The ice regions in the ice charts were updated according to a SAR segmentation, and new ice parameter values were assigned to each SAR segment based on the SAR backscattering and the ice thickness range at that location.

As a proxy of local eutrophication in the study area, the long-term average and maximum of surface chlorophyll $a$ values obtained from SeaWiFS chlorophyll composites were used. Each image had a spatial resolution of $11 \mathrm{~km} \times 11 \mathrm{~km}$. Cloud gaps were filled by an interpolation procedure over a maximum distance of $100 \mathrm{~km}$.

The contribution of site, sediment type, and dominant phytobenthic species to the abundance and biomass of macrozoobenthos was tested by one-way ANOVA after checking for normality of the data (Kolmogorov-Smirnov test for goodness of fit) and homogeneity of variance (Bartlett's and Hartley's tests) (Sokal \& Rohlf, 1981).

Multivariate data analyses were performed by the statistical program 'PRIMER' version 6.1.5 (Clarke \& Gorley, 2006). In order to increase the signal-to-noise ratio in the multivariate analysis an average of three replicates in each site was used to construct similarity matrices. A zero-adjusted Bray-Curtis similarity measure was used. Data was log-transformed to reduce the contribution of abundant species to similarity measure. Ordination was made by nonmetric multidimensional scaling (MDS) (Clarke \& Green, 1988). Environmental (abiotic and plant) variables were normalized and then the Euclidean distance matrix was calculated. BEST analysis (BIOENV procedure) was used to relate the similarity matrices of environmental variables to the similarity matrices of the abundance and biomass of benthic invertebrates. A global BEST match permutation test was run to examine the statistical significance of the observed relationships between environmental variables and biotic patterns. The statistical differences in invertebrate 
assemblages between defined groups were obtained by the ANOSIM permutation test (Clarke \& Green, 1988; Clarke, 1993). The contribution of each species to dissimilarities was investigated using the similarities percentages procedure (SIMPER) (Clarke, 1993).

\section{RESULTS}

The total abundance and biomass of macrozoobenthos varied largely between the transects of the study area (Table 1, Fig. 1). The highest mean abundance was found in the outermost part of the Gulf of Riga (transect 4; 5838 ind $\mathrm{m}^{-2}$ ) and the lowest on the adjacent area across the Irbe Strait (transect 9; 71 ind $\mathrm{m}^{-2}$ ). The highest mean biomass was recorded in the easternmost part of the gulf (transect 6; $71 \mathrm{~g} \mathrm{dw} \mathrm{m}^{-2}$ ) and the lowest adjacent to the Daugava River mouth and in the coastal zone of Ruhnu Island (transects 7 and 10, respectively; $7 \mathrm{~g} \mathrm{dw} \mathrm{m}^{-2}$ in both regions). The distribution pattern of abundance and biomass values along the depth gradient was not consistent. Depending on the location of the transect, denser populations were observed in the shallower areas (transects 4 and 5), at moderate depths (transects 1, 2, 7, 8, and 9), or in the deeper areas (transects 3,6, and 10).

BIOENV analysis showed that salinity and vegetation type were the environmental variables predicting best the abundance of benthic invertebrate communities (Spearman $\rho_{\text {salinity }+ \text { vegetation }}=0.332$; separate contributions of environmental variables were $\rho_{\text {salinity }}=0.243$ and $\rho_{\text {vegetation }}=0.178 ; p=0.04$ ). As for biomass, chlorophyll $a$ and sediment type also contributed to the model (Spearman $\rho_{\text {salinity+vegetation+sediment+chlorophyll }}=0.326$; separate contributions of environmental variables were $\rho_{\text {salinity }}=0.216, \rho_{\text {vegetation }}=0.224, \rho_{\text {chlorophyll }}=0.110$, and $\rho_{\text {sediment }}=0.265 ; p=0.02$ ).

The univariate measures of benthic invertebrate abundance and biomass also varied along the salinity gradient and among different bottom and vegetation types (Fig. 2). Vascular plant communities were characterized by a higher abundance of insects and gastropods of freshwater origin (Lymnaea sp., Bithynia

Table 1. One-way ANOVAs of the effects of sediment and vegetation types on the abundance and biomass values of different trophic groups of benthic invertebrates. Significant differences $(p<0.05)$ are in bold

\begin{tabular}{c|r|r|r|r|r|r}
\hline Model & Total & $\begin{array}{c}\text { Suspension } \\
\text { feeder }\end{array}$ & Herbivore & Carnivore & Detrivore & Omnivore \\
\hline $\begin{array}{l}\text { Sediment } \\
\text { Abundance }\end{array}$ & $<\mathbf{0 . 0 0 1}$ & 0.069 & $\mathbf{< 0 . 0 0 1}$ & $<\mathbf{0 . 0 0 1}$ & $<\mathbf{0 . 0 0 1}$ & $<\mathbf{0 . 0 0 1}$ \\
$\begin{array}{l}\text { Biomass } \\
\text { Vegetation }\end{array}$ & 0.573 & 0.809 & $<\mathbf{0 . 0 0 1}$ & 0.988 & 0.209 & $<\mathbf{0 . 0 0 1}$ \\
Abundance & $\mathbf{0 . 0 2 5}$ & $\mathbf{0 . 0 0 1}$ & $\mathbf{< 0 . 0 0 1}$ & 0.202 & 0.660 & $<\mathbf{0 . 0 0 1}$ \\
Biomass & $<\mathbf{0 . 0 0 1}$ & $\mathbf{< 0 . 0 0 1}$ & $\mathbf{< 0 . 0 0 1}$ & $<\mathbf{0 . 0 0 1}$ & 0.170 & $<\mathbf{0 . 0 0 1}$
\end{tabular}



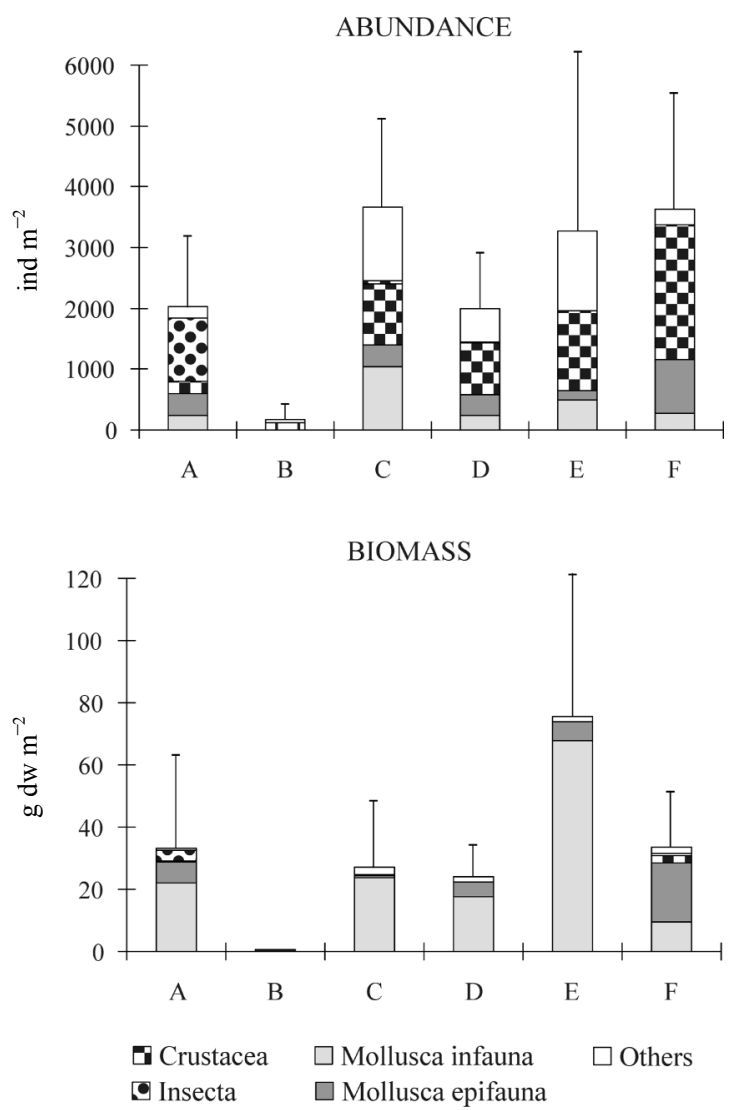

Fig. 2. Average abundance and biomass values of different taxonomic groups of benthic invertebrates with $95 \%$ confidence intervals in shallow water vascular plant communities $(n=18)(\mathrm{A})$, shallow $(<1 \mathrm{~m})$ unvegetated sandy bottoms at the south-eastern $(n=9)(\mathrm{B})$ and north-western coast $(n=12)(C)$, unvegetated sand and gravel bottoms at $1-4 \mathrm{~m}$ depth $(n=27)(\mathrm{D})$, unvegetated sand and gravel bottoms at 5-6 m depth $(n=8)(\mathrm{E})$, and hard bottom types (boulders or limestone) with algal vegetation $(n=20)(\mathrm{F})$.

tentaculata (L.)), while biomass was dominated by burrowing mussels (Macoma balthica L. and Cerastoderma glaucum Bruguière). Unvegetated bottom types were dominated by crustaceans (mainly Gammarus spp. and Corophium volutator (Pallas)), followed by polychaetes (Hediste diversicolor (O. F. Müller) and Marenzelleria neglecta Sikorski \& Bick) and oligochaetes. The abundance was highest on shallow $(<1 \mathrm{~m})$ sandy bottoms in the north-eastern part of the gulf $\left(3700\right.$ ind $\mathrm{m}^{-2}$ ) while the shallow areas of the south-eastern part were very poor in macrofauna (only 160 ind $\mathrm{m}^{-2}$ ). The biomass was mainly formed by burrowing mussels, M. balthica and C. glaucum in shallow areas and M. balthica and Mya arenaria L. in deeper and coarser bottoms. The biomass was highest in deep (5-6 m) gravel bottoms $\left(76 \mathrm{~g} \mathrm{dw} \mathrm{m}^{-2}\right)$. Hard bottom algal communities were composed mainly of Theodoxus fluviatilis (L.), Jaera albifrons Leach, Idotea 
chelipes (Slabber), I. baltica (Pallas), Gammarus spp., and the sedentary mussels Dreissena polymorpha (Pallas) and Mytilus trossulus Gould. The last two mussel species were found in the same samples at four sites.

Five different trophic groups of macrozoobenthos were distinguished in the study range: omnivores, detrivores, carnivores, herbivores, and suspension feeders (Fig. 3). Detrivores (mainly M. balthica) contributed significantly to the total abundance in the northern part of the gulf. The proportion of herbivores was higher in the eastern part of the gulf (T. fluviatilis in the south-eastern part and Hydrobia spp. and Lymnaea spp. in the north-eastern part of the gulf). As to the biomass, detrivores ( $M$. balthica) were still the dominant feeding type in the northern part of the gulf, with a significant proportion of suspension feeders (D. polymorpha) in the vicinity of Pärnu Bay. The share of macrozoobenthos of different feeding types was similar in the southern part of the gulf. The proportion of suspension feeders was highest on transects 6 and 8 . Transect 6 was unique representing either the communities of northern type (by biomass) or southern type (by abundance).

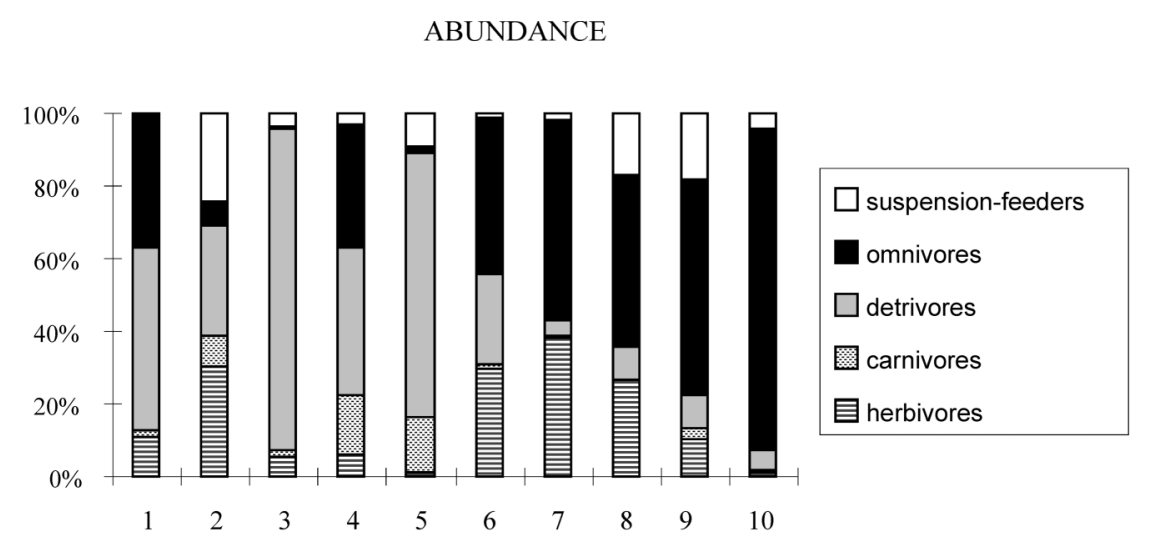

BIOMASS

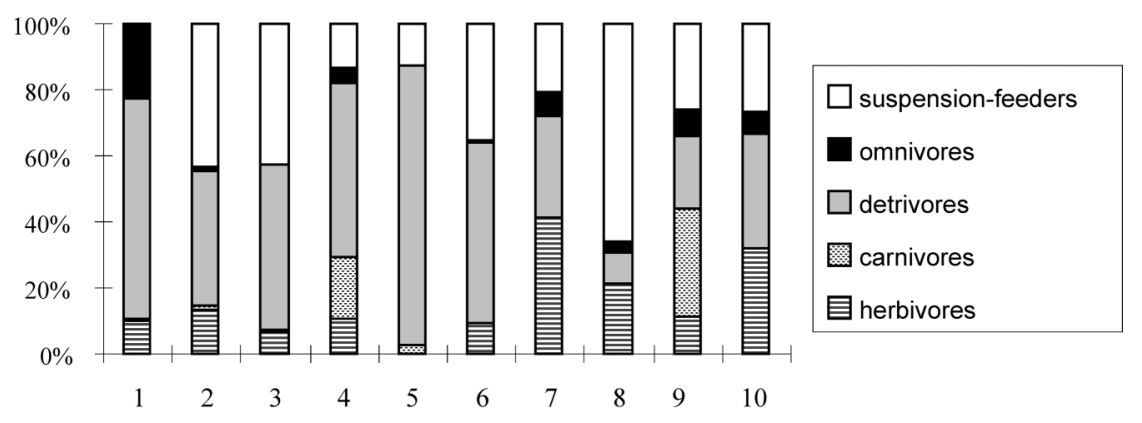

Fig. 3. Proportion of different trophic groups in terms of abundance and biomass at different transects. 
Salinity explained a large part of the observed variability of the benthic invertebrate communities in the Gulf of Riga (Fig. 4). Of the three groups of species (marine, brackish-water, and freshwater) brackish and freshwater species had a higher proportion in the southernmost (transects 7 and 8) and the northeastern part of the gulf (transect 2). These transects are influenced by the inflow of either the Daugava or the Pärnu River.

According to one-way ANOVA (Table 1), sediment type affected the total abundance values of macrozoobenthos whereas dominant plant species was significant in describing both the total abundance and biomass values of macrozoobenthos. Higher abundances were found on stone, sandy gravel, and gravelly clay bottoms, lower on clayey sand and sand bottoms. The lowest abundance and biomass were found on Zannichellia palustris L. community, the highest on $F$. vesiculosus and Cladophora rupestris Kütz. community. The density of herbivores and omnivores was significantly higher on stone bottoms, that of detrivores on sandy gravel and gravelly clay bottoms. Suspension feeders preferred communities dominated by F. vesiculosus, F. lumbricalis, and Myriophyllum spicatum L., herbivores the $F$. vesiculosus community, carnivores $F$. lumbricalis and M. spicatum

ABUNDANCE

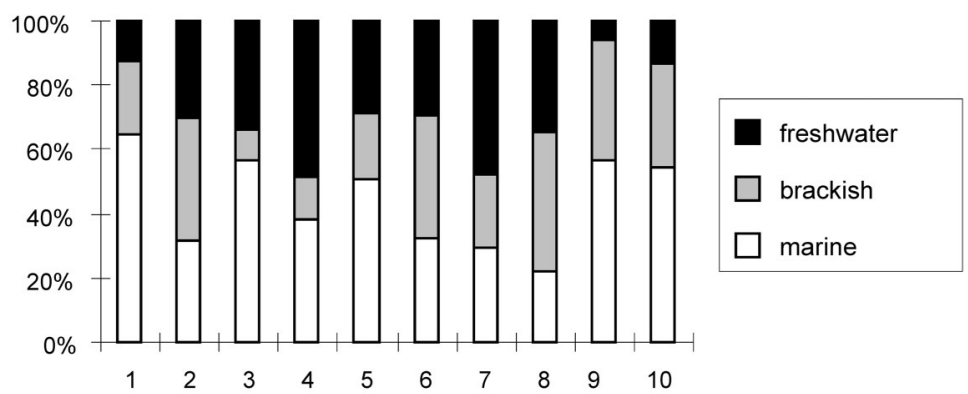

BIOMASS

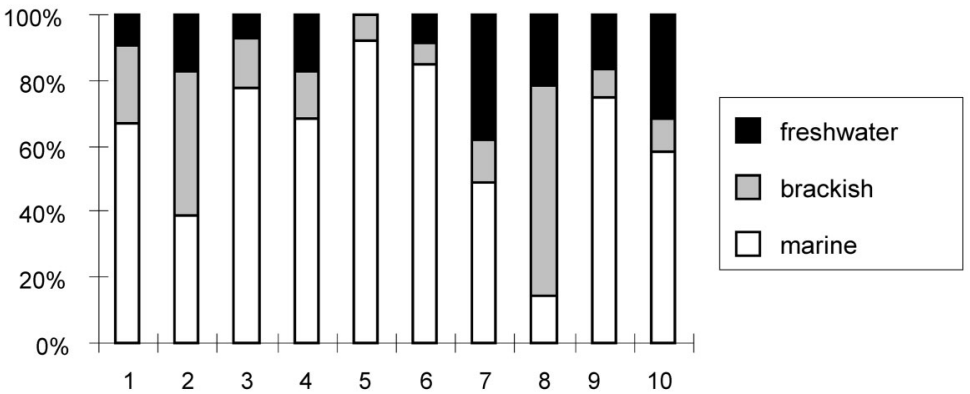

Fig. 4. Proportion of marine, brackish-water, and freshwater species in terms of abundance and biomass at different transects. 
communities, and omnivores $C$. rupestris and $F$. vesiculosus communities. The abundance and biomass of detrivores were independent of the type of plant communities around the sampling area.

Ordination of log-transformed abundance and biomass data of macrozoobenthos did not produce very distinguished groups (Fig. 5). Considering the biomass values, transect 2 was clearly separated from transects 8,9 , and 10 (ANOSIM, $p<0.05)$, transect 3 from transects 8 and $9(p=0.03)$, and transect 4 from transect 7 $(p=0.03)$. The most of dissimilarities were due to M. balthica, C. glaucum, Bithynia tentaculata L., $H$. diversicolor, D. polymorpha, and T. fluviatilis. The first three species had a higher biomass in the northern part of the gulf. On the contrary, T. fluviatilis was more common at the southern coasts of the gulf. At the north-eastern and southern coasts $D$. polymorpha thrived whereas $H$. diversicolor occurred with a higher biomass in the western side of the gulf. The ordination of macrozoobenthos by abundance shows the transects to be even more similar to one another.

Surprisingly, there was only a weak relationship between bottom types and the structure of macrozoobenthic communities. Significant differences were observed comparing very different substrate types such as stone bottoms with gravel-sand bottoms (ANOSIM, $p<0.01$ ). Stone bottoms were characterized by the highest density of D. polymorpha, T. fluviatilis, Turbellaria, Gammarus oceanicus Segerstråle, G. salinus Spooner, G. zaddachi Sexton et Spooner, and C. glaucum. The highest abundance of $M$. neglecta and Oligochaeta was observed on sandy gravel bottoms.

There was a significant difference between the areas devoid of vegetation and the $Z$. palustris community (calculations based on macrozoobenthic biomass data, ANOSIM, $p=0.05$ ) and between F. vesiculosus and Potamogeton pectinatus $\mathrm{L}$.
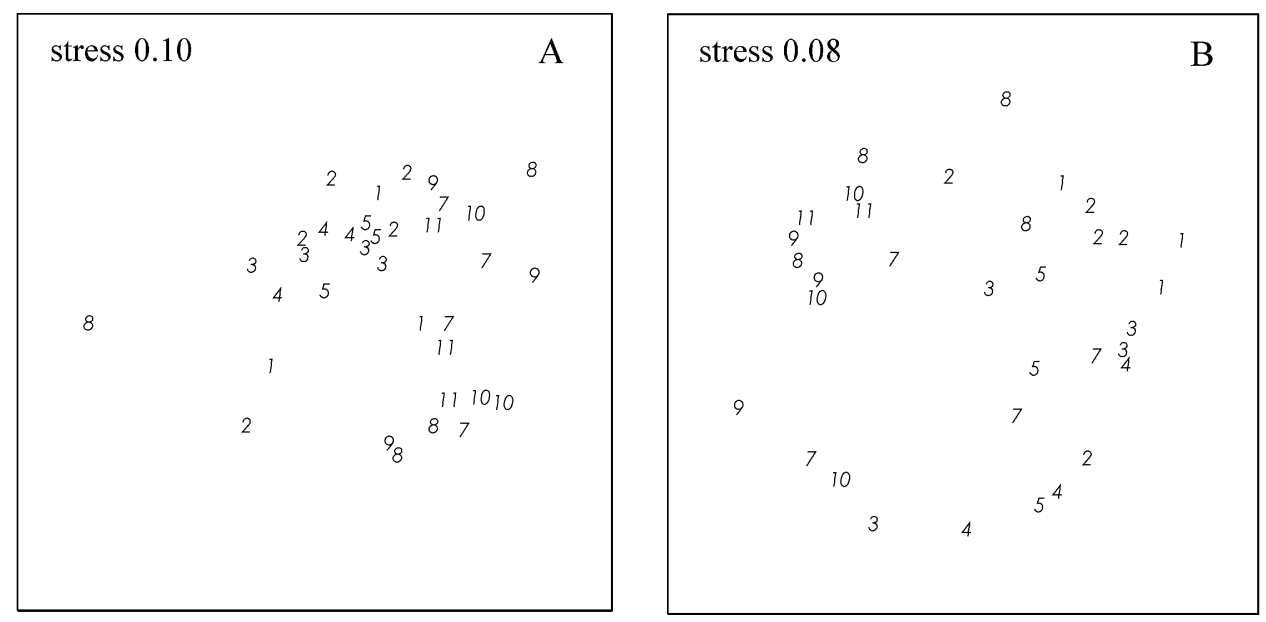

Fig. 5. MDS ordination of sampling sites based on benthic invertebrate log-transformed abundance (A) and biomass (B). 
communities (abundance data, $p=0.03$ ). In the former case, T. fluviatilis, $M$. balthica, and $H$. diversicolor contributed to the differences between these two community types. The last two species had a higher biomass on unvegetated areas and $T$. fluviatilis in the Z. palustris community. Comparison of $F$. vesiculosus and P. pectinatus communities showed that J. albifrons, Gammarus spp., T. fluviatilis, I. neglecta, and M. balthica had higher abundance in the Fucus belt whereas only Chironomidae of the P. pectinatus community outnumbered those of the $F$. vesiculosus community.

\section{DISCUSSION}

The study showed that the large-scale distribution of benthic invertebrate communities in the Gulf of Riga was most likely driven by changes in salinity and benthic macrophyte communities. The benthic biomass was additionally affected by water quality. Although the role of salinity in determining the largescale invertebrate patterns was demonstrated earlier in the whole Baltic Sea range (Bonsdorff \& Pearson, 1999), the relative contribution of macrovegetation and eutrophication has not been assessed. Locally, however, the role of macrophytes in providing structured habitats for benthic invertebrates may have been well established (e.g. Kotta \& Orav, 2001). Besides providing the habitat, benthic macrophytes fulfil multiple ecological functions, including improvement of sediment stability, food regime, and water quality as well as protection from wave disturbance (e.g. Orav-Kotta \& Kotta, 2004; Torn et al., 2010).

Our results clearly demonstrated that in the Gulf of Riga the abundance of benthic invertebrates was fairly insensitive to variability in eutrophication (i.e. long-term average of water chlorophyll $a$ content) whereas their biomass was strongly related to changes in water quality. Specifically, strong gradients were observed in water chlorophyll $a$ along the major river mouths; moreover, such gradients matched with the biomass patterns of the suspension-feeding bivalves. This advocates the use of invertebrate biomass rather than abundance for the assessment of the status of the Gulf of Riga coastal areas in the frame of The European Union Water Framework Directive (Kotta et al., 2012).

The abundance values of macrozoobenthos found in this study were of the same magnitude as those found in other coastal areas in the northern Baltic Sea (e.g. Elmgren \& Ganning, 1974; Skult, 1977; Orav et al., 2000). However, the values of biomass found in the Gulf of Riga were much lower than those in the Baltic Proper. This corresponds to the scarcer M. trossulus population due to lower salinity values in the Gulf of Riga. The biomass of the brackish-water D. polymorpha was not high enough to compensate for this.

The proportion of suspension feeders was fairly low in the vicinity of the mouth of the Daugava River, the main pollution source of the Gulf of Riga (transect 7). At the same time the abundance and biomass of suspension feeders (mainly D. polymorpha) were very high on both sides of the Daugava River mouth (transects 6 and 8). A lack of the suspension feeders in the vicinity of the Daugava 
River mouth is by no means related to the water quality but reflects the prevalence of soft substrate in the area, not suitable for any suspension-feeding mussels, including D. polymorpha, inhabiting the south-eastern Gulf of Riga.

Higher biomass of detrivores in the northern part of the gulf is related to different coastal morphology. Due to the wider coastal zone and lower input of wave energy, sedimentation is more intensive in the northern part as compared to the southern part of the gulf, hence favouring the development of dense populations of e.g. M. balthica.

Comparison of the proportions of benthic invertebrates of different feeding type in unvegetated and vegetated areas revealed that the latter were characterized by a much smaller proportion of suspension feeders in the vicinity of the Daugava and Pärnu river mouths but not in the coastal sea of Saaremaa Island. In general, macrophytes and mussels are expected to compete for space and an inverse relationship between these trophic guilds is expected. Specifically, macroalgae are known to outcompete benthic suspension feeders at shallow depths, and lush macrophyte communities are therefore often characterized by low densities of suspension feeders (Janke, 2006). Although this may be a plausible mechanism in the vicinity of river mouths where the fast-growing phanerogams such as Potamogeton spp. prevail, in the northern Gulf of Riga with the presence of small-sized macroalgae the mussels are likely facilitating algal growth in this dynamic and physically disturbed habitat (Kotta et al., 2009a).

Shallow-water benthic invertebrate communities are expected to face strong disturbances by ice and waves. It is therefore surprising that the ice effects were negligible in all statistical models applied. It is plausible, though, that strong seasonality of the shallow water ecosystem of the Gulf of Riga is behind the lack of a such relationship (Kotta et al., 2008). In the study area virtually the whole benthic invertebrate biomass is produced during the spring-summer season and thus communities respond to environmental variables in this period (i.e. water temperature, salinity, nutrients) rather than to any ice-mediated effects.

According to Järvekülg (1961, 1979), M. balthica dominated the whole sublittoral zone of the Gulf of Riga in the 1960s. Nowadays this is also true and only locally $M$. neglecta, $H$. diversicolor, D. polymorpha, or $T$. fluviatilis may take the leading role. Unfortunately, due to the differences in methods, it is hard to compare how the species diversity has changed. Nevertheless, earlier studies demonstrate that the present-day communities are more uniform (shown by lower dissimilarities/distances between the stations) compared to the past communities (Kotta et al., 2012). Besides, the decline of phytophilous species in the northern part of the gulf was documented by Kotta \& Kotta (1997). In the 1960s the average abundance and biomass values were respectively $840 \mathrm{ind} \mathrm{m}^{-2}$ and $3 \mathrm{~g} \mathrm{ww} \mathrm{m}^{-2}$ at $0.1-0.4 \mathrm{~m}$ depth and 2210 ind $\mathrm{m}^{-2}$ and $62 \mathrm{~g} \mathrm{ww} \mathrm{m}^{-2}$ at $0.5-9 \mathrm{~m}$ (Järvekülg, 1979). We measured $2640 \mathrm{ind} \mathrm{m}^{-2}$ and $18 \mathrm{~g} \mathrm{dw} \mathrm{m}^{-2}$ in the shallower areas and 2475 ind $\mathrm{m}^{-2}$ and $35 \mathrm{~g} \mathrm{dw} \mathrm{m}^{-2}$ in the deeper areas, respectively. The average ratio of wet weight to dry weight in the study area was about 2.8. Figure 6 compares the average abundance and biomass data of benthic 


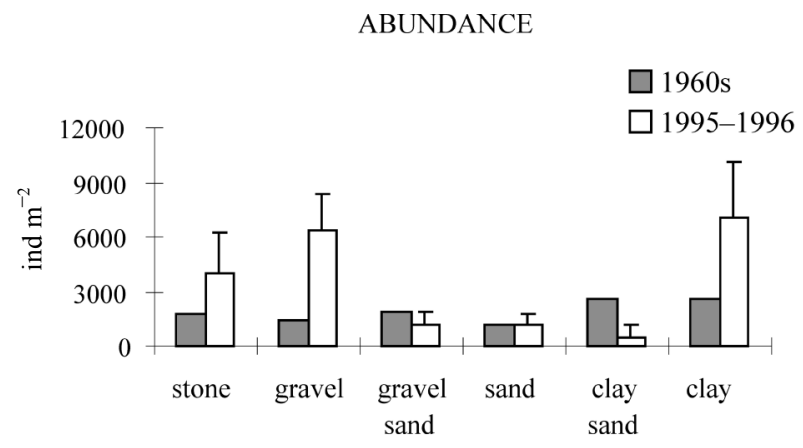

BIOMASS

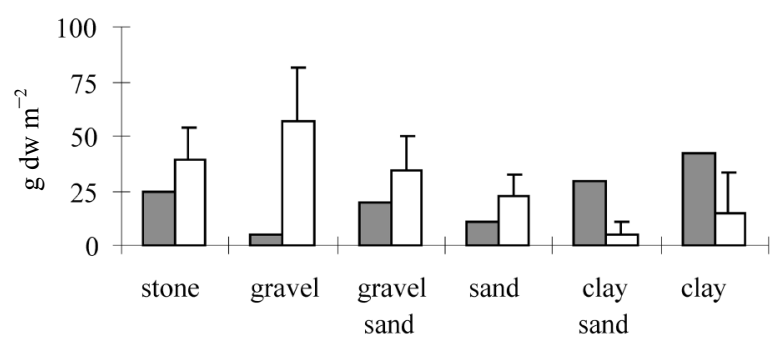

Fig. 6. Average abundanc and biomass of benthic invertebrates on different sediment types in the coastal sea of the Gulf of Riga in the 1960s (Järvekülg, 1979) and 1995-1996. Confidence intervals are shown for 1995-1996.

invertebrates at different sediment types between the 1960s and this study. As the methods used by Järvekülg underestimated the abundance and biomass of macrozoobenthos on stone and gravel bottoms (especially at $0.1-2 \mathrm{~m}$ ), the magnitude of the actual changes was smaller than presented in the figure. Hence, it is likely that the biomass and abundance of benthic invertebrates have not significantly increased in the shallow water coastal range of the Gulf of Riga during the last 30 years.

\section{CONCLUSIONS}

On the basis of shallow water benthic invertebrate assemblages, the Gulf of Riga may be broadly divided into southern and northern areas. Among abiotic variables salinity, macrophyte communities, and nutrient input by rivers explain a significant proportion of variation in the abundance and biomass of macrozoobenthos. Despite the heavy nutrient loading into the Gulf of Riga the biomass and abundance of benthic invertebrates have not substantially increased during the last 30 years. The overall condition of benthic invertebrate assemblages seems to be good compared to the similar areas in the Northern Baltic Sea. 


\section{ACKNOWLEDGEMENTS}

The sampling was carried out within the framework of the littoral project of the Gulf of Riga financed by the Nordic Council. Funding for this research was provided by Institutional research funding IUT02-20 of the Estonian Research Council and by the projects 'EstKliima' No. 3.2.0802.11-0043 and 'The status of marine biodiversity and its potential futures in the Estonian coastal sea' No. 3.2.0802.11-0029 of the Environmental Protection and Technology Programme of the European Regional Fund.

\section{REFERENCES}

Bendtsen, J., Gustafsson, K. E., Söderkvist, J. \& Hansen, J. L. S. 2009. Ventilation of bottom water in the North Sea-Baltic Sea transition zone. Journal of Marine Systems, 75, 138-149.

Bonsdorff, E. \& Pearson, T. H. 1999. Variation in the sublittoral macrozoobenthos of the Baltic Sea along environmental gradients; a functional-group approach. Australian Journal of Ecology, 24, 312-326.

Clarke, K. R. 1993. Non-parametric multivariate analyses of changes in community structure. Australian Journal of Ecology, 18, 117-143.

Clarke, K. R. \& Gorley, R. N. 2006. Primer v6. User Manual/Tutorial. Primer-E, Plymouth.

Clarke, K. R. \& Green, R. H. 1988. Statistical design and analysis for a 'biological effects' study. Marine Ecology Progress Series, 46, 213-226.

Elmgren, R. \& Ganning, B. 1974. Ecological studies of two shallow brackish water ecosystem. Contribution from the Askö Laboratory, University of Stockholm, Sweden, 6, 1-56.

HELCOM. 1993. First assessment of the state of the coastal waters of the Baltic Sea. Baltic Sea Environment Proceedings, 54, 1-160.

Hiscock, K. \& Hoare, R. 1973. A portable suction sampler for rock epibiota. Helgoländer wissenshaftliche Meeresuntersuchungen, 25, 35-38.

Janke, K. 2006. Biological interactions and their role in community structure in the rocky intertidal of Helgoland (German Bight, North Sea). Helgoländer Marine Research, 44, 219-263.

Järvekülg, A. 1961. Mõnede bentiliste ja nektobentiliste selgrootute levikust Riia lahe kirdeosas. Eesti NSV TA Toimetised. Bioloogia, 10, 214-230.

Järvekülg, A. 1962. Põhjaloomastiku varudest Riia lahe kirdeosas. Kalatööstus, 1, 48-52.

Järvekülg, A. 1979. Benthic Fauna in the Eastern Part of the Baltic Sea. Valgus, Tallinn (in Russian).

Kangas, P. 1972. Quantitative sampling equipment for the littoral benthos. II. IBP $i$ Norden, 10, 9-16.

Kautsky, H. \& Van der Maarel, E. 1990. Multivariate approaches to the variation in phytobenthic communities and environmental vectors in the Baltic Sea. Marine Ecology Progress Series, 60, 169-184.

Kautsky, H., Martin, G., Mäkinen, A., Borgiel, M., Vahteri, P. \& Rissanen, J. 1999. Structure of phytobenthic and associated animal communities in the Gulf of Riga. Hydrobiologia, 393, 191-200.

Kotta, I. \& Kotta, J. 1997. Changes in zoobenthic communities in Estonian waters between the 1970's and 1990's. An example from the southern coast of Saaremaa and Muuga Bay. In Proceedings of the 14th Baltic Marine Biologists Symposium (Ojaveer, E., ed.), pp. 70-79. Estonian Academy Publishers, Tallinn.

Kotta, J. \& Kotta, I. 1995. The state of macrobenthos of Pärnu Bay in 1991 as compared to 19591960. Proceedings of the Estonian Academy of Sciences. Ecology, 5, 26-37. 
Kotta, J. \& Orav, H. 2001. Role of benthic macroalgae in regulating macrozoobenthic assemblages in the Väinameri (north-eastern Baltic Sea). Annales Zoologici Fennici, 38, 163-171.

Kotta, J., Lauringson, V. \& Kotta, I. 2007. Response of zoobenthic communities to changing eutrophication in the northern Baltic Sea. Hydrobiologia, 580, 97-108.

Kotta, J., Lauringson, V., Martin, G., Simm, M., Kotta, I., Herkül, K. \& Ojaveer, H. 2008. Gulf of Riga and Pärnu Bay. In Ecology of Baltic Coastal Waters (Schiewer, U., ed.), pp. 217-243. Ecological Studies, 197. Springer.

Kotta, J., Herkül, K., Kotta, I., Orav-Kotta, H. \& Lauringson, V. 2009a. Effects of the suspension feeding mussel Mytilus trossulus on a brackish water macroalgal and associated invertebrate community. Marine Ecology, 30, 56-64.

Kotta, J., Kotta, I., Simm, M. \& Põllupüü, M. 2009b. Separate and interactive effects of eutrophication and climate variables on the ecosystem elements of the Gulf of Riga. Estuarine, Coastal and Shelf Science, 84, 509-518.

Kotta, J., Lauringson, V., Kaasik, A. \& Kotta, I. 2012. Defining the coastal water quality in Estonia based on benthic invertebrate communities. Estonian Journal of Ecology, 61, 86-105.

Lagzdiňš, G. S. 1975. Benthic fauna in the Gulf of Riga as the indicator of pollution. In Fundamentals of Bioproductivity of the Inner Water Bodies of the Baltic Region. Proceedings of XVIII Scientific Conference of the Research of the Inner Waterbodies of the Baltic States (Virbitskas, Yu., Krotas, R. \& Manyukas, I., eds.), pp. 429-430. Institute of Zoology and Parasitology, Academy of Sciences of Lithuanian SSR (in Russian).

Laine, A. O., Andersin, A.-B., Leiniö, S. \& Zuur, A. F. 2007. Stratification-induced hypoxia as a structuring factor of macrozoobenthos in the open Gulf of Finland (Baltic Sea). Journal of Sea Research, 57, 65-77.

Leppäkoski, E. 1975. Assessment of degree of pollution on the basis of macrozoobenthos in marine and brackish-water environments. Acta Academiae Aboensis. Series B Mathematica et Physica, 35, 1-90.

Ojaveer, H. 1997. Composition and dynamics of fish stocks in the Gulf of Riga ecosystem. Dissertationes Biologicae Universitatis Tartuensis, 31, 1-138.

Orav, H., Kotta, J. \& Martin, G. 2000. Factors affecting the distribution of benthic invertebrates in the phytal zone of the north-eastern Baltic Sea. Proceedings of the Estonian Academy of Sciences. Biology. Ecology, 49, 253-269.

Orav-Kotta, H. \& Kotta, J. 2004. Food and habitat choice of the isopod Idotea baltica in the northeastern Baltic Sea. Hydrobiologia, 514, 79-85.

Shurin, A. T. 1953. Benthic fauna of the Gulf of Riga. Trudy Latviiskogo Otdeleniya VNIRO, 1 , 77-113 (in Russian).

Shurin, A. T. 1960. Benthic fauna of the Gulf of Riga and its dispersion patterns. Trudy VNIRO, 42, 37-60 (in Russian).

Shurin, A. T. 1961. Assemblages of benthic fauna in the Gulf of Riga. Trudy NIIRH SNH Latviiskogo SSR, 3, 343-368 (in Russian).

Skult, P. 1977. Composition of phytal macrofauna communities on transects extending seawards from Helsinki. Memoranda Societatis pro Fauna et Flora Fennica, 53, 43-56.

Sokal, R. R. \& Rohlf, F. J. 1981. Biometry. The Principles and Practice of Statistics in Biological Research. W.H. Freeman, San Francisco, California.

Suursaar, Ü. 1995. Nutrients in the Gulf of Riga. In Ecosystem of the Gulf of Riga Between 1920 and 1990 (Ojaveer, E., ed.), pp. 41-50. Academia, 5. Estonian Academy Publishers, Tallinn.

Terlizzi, A. \& Schiel, D. R. 2009. Patterns along environmental gradients. In Marine Hard Bottom Communities (Wahl, M., ed.), pp. 101-112. Ecological Studies, 206. Springer, Heidelberg.

Torn, K., Martin, G., Kotta, J. \& Kupp, M. 2010. Effects of different types of mechanical disturbances on a charophyte dominated macrophyte community. Estuarine, Coastal and Shelf Science, 87, 27-32. 